\title{
EFFECT OF DAILY WEIGHT GAIN ON AGE AT FIRST CALVING AND SUBSEQUENT MILK YIELD OF HOLSTEIN HEIFERS IN EGYPT
}

\author{
R.R. Sadek, G. Ashour, M.A.M. Ibrahim and A.M. Samoul* \\ Department of Animal Production, Faculty of Agriculture, University of Cairo, Giza, Egypt \\ *Corresponding Email:alisamool@hotmail.com
}

\section{SUMMARY}

A total number of 1152 complete lactation records for 576 Holstein cows were collected from two commercial farms (Copenhagen and Sami Asaad farm) during the period from year 2007 to 2010 to determine the effect of average daily weight gain $(A D G)$ from birth to conception of Holstein heifers on their age at first calving (AFC) and subsequent milk yield. Heifers were divided into four groups $\left(G^{s}\right)$ based on their ADG as $650 \mathrm{~g} /$ day, $775 \mathrm{~g} /$ day, $875 \mathrm{~g} /$ day and $950 \mathrm{~g} /$ day for G1, G2, G3 and G4, respectively. Heifers of G4 reached the AFC 5.3 month earlier $(P<0.001)$ than those of $G 1$. ADG had positive effect on productive traits of the first two lactations. Cows of G4 had a similar 305 days milk yield in the first lactation compared to G1 but, scored non-significant higher milk yield in the second one by $535 \mathrm{~kg}$.

G4 had non-significant increase in milk yield / day of cow age till the end of the first lactation (MY1/DCA) compared with G1. Milk yield / day of cow age of G4 till the end of the second lactation (MY2/DCA) increased $(P<0.01)$ by $12.7 \%$ compared to $G 1$.

Days open of $G 4$ in the first lactation (DO1) was shorter $(P<0.05)$ than that of $G 1$ by 44 days. This trend extended to the second lactation, however, it was insignificant. The present results showed that productive and reproductive performance of the faster growing Holstein heifers is better than that of slower ones. The ADG of Holstein heifers during the period from birth to conception affected significantly AFC, DO1 and MY2/DCA. G4 calved for the first time 5.3 months earlier, produced $535 \mathrm{~kg}$ more milk and had shorter days open by 67 days till the end of second lactation compared with Gl.

Keywords: average daily gain, age at first calving, 305-day milk yield, days open, Holstein, Egypt

\section{INTRODUCTION}

Rearing heifers to join milking herd at an appropriate age and body weight, is a fundamental to enable heifers to express full lifetime potentiality. Body weight at first insemination is based on age, nutritional level and health condition. Poor growth rate may postpone age at first calving (AFC) (Johnson et al., 2011). Cost of rearing replacement heifers could be reduced in case of high growth rate, which is reflected on early age at first calving (Hultgren et al., 2011). Reducing age at first calving would minimize cost of raising heifers, shorten generation interval and increase the expected number of lactations given during productive life (Ashmawy, 1985).

There are inconsistent results in the literature concerning the effect of pre-puberty ADG on the subsequent milk production of dairy heifers. High growth rate was reported to reduce age at first pregnancy (Capuco et al., 1995 and Sejrsen and Purup, 1997). Meanwhile other studies indicated that increasing ADG was linked to low milk production (Van Amburgh et al., 1998; Lammers et al., 1999; Abeni et al., 2000 and Radcliff et al., 2000) due to reducing mammary parenchymal development (Meyer et al., 2004). Pirlo et al. (1997) and Waldo et al. (1998) stated no association between ADG and milk production.

No results are available; under Egyptian conditions; concerning the effect of ADG before conception of Holstein heifers on the subsequent milk production. Therefore, this study was conducted to test the effect of pre-conception ADG on productive and reproductive performance of Holstein heifers in two commercial farms under intensive production system in Egypt.

\section{MATERIALS AND METHODS}

\section{Sources of data}

A total number of 1152 lactation records for 576 Holstein cows calved during the period from January 2007 to December 2010 were collected from two commercial farms in Egypt. The first farm is Alexandria Copenhagen Company for Milk and Meat Production (FARM1), located at El-Nubariya district, EL-Beheira governorate, $150 \mathrm{~km}$ northwest of Cairo. The second is Sami Asaad farm (FARM2), located at Abu Hammad district, Sharkia governorate, $100 \mathrm{~km}$ northeast of Cairo, $15 \mathrm{~km}$ east of Zagazig city.

\section{Herd management}

Management practices in both farms under study were almost the same. Cows were fed a total mixed ration (TMR) throughout the year. The TMR consisted of concentrates, corn silage and alfalfa hay. Egyptian clover (Trifolium alexandrinum) was offered during winter (Dec. - Feb.) and spring (March - May) and replaced by Egyptian clover hay during summer (June - Aug.) and autumn (Sep. - Nov.). Ambient temperature was moderate during winter and spring, while it was hot during summer and autumn. Rations 
were offered twice a day according to NRC (2001) requirements. New born heifers were allowed to suckle their dams till the third day post-partum. Thereafter, they were fed artificially raw milk and milk replacer until weaning at about $90 \mathrm{~kg}$ body weight, in addition to the starter ( $22 \%$ crude protein), which was offered starting from the second week of age. Fresh water was made available all the time.

Heifers were weighed monthly to calculate ADG from birth to conception. It was calculated by dividing the total weight gain by the number of days of that period. Heifers were inseminated for the first time when reaching about $360 \mathrm{~kg}$ of body weight. Heat was detected visually and heifers that displayed estrous symptoms were inseminated by frozen semen of the best 100 total predicated index Holstein bulls in USA and Canada. Cows were machine milked daily at eight hours intervals starting at 06:00 am. Daily milk yield was recorded for each cow till the end of lactation. Cows were dried off about two months before the expected calving date or when milk yield dropped to less than $7 \mathrm{~kg} /$ day. Cows were vaccinated against various bacterial and viral diseases in due time and were de-wormed against external and internal parasites, twice yearly.

\section{Studied traits}

a. Age at first calving (AFC, mo) was defined as days from birth to first calving dividing by 30.5 .

b. 305-day milk yield (305-dMY, kg) was calculated as the total milk production throughout the first 305 days for cows milking more than 305 days or through the drying off date if it occurred normally prior to 305 days in milk. The 305-day milk of cows of incomplete lactations due to selling, death or slaughtering, yield was estimated using the equation approved by the International Committee for Animal Recording (ICAR, 2000) as follows:

The 305-day milk yield $=[($ TMY X 405 $) /(100+$ LP $)]$.

c. Milk yield / day of cow age till the end of the first lactation (MY1/DCA, $k g$ ) was calculated by dividing the total milk yield produced throughout the first lactation by the number of days from birth till the end of the first lactation.

d. Milk yield / day of cow age till the end of the second lactation (MY2/DCA, $k g$ ) was calculated by dividing the total milk yield produced throughout the first two lactations by the number of days from birth till the end of the second lactation.

e. Days open (DO, day) was defined as days from calving until conception. It was calculated by subtracting the previous calving date from the subsequent conception date.

\section{Statistical analyses}

In order to determine effects of daily gain on milk production and reproductive traits, heifers were classified according to their average daily gain (ADG) into four groups $(\mathrm{G})$ depending on the standard deviation distribution of ADG as indicated in Table (1).

Table 1. Distribution of Holstein heifers according to their average daily gain

\begin{tabular}{ccccc}
\hline Groups & NO. & ADG $(\mathbf{g m})$ & Min. $(\mathbf{g m})$ & Max. $(\mathbf{g m})$ \\
\hline G1 & 124 & 650 & 427 & 699 \\
G2 & 300 & 775 & 700 & 849 \\
G3 & 86 & 875 & 850 & 899 \\
G4 & 66 & 950 & 900 & 1046 \\
\hline Overall & 576 & 780 & 720 & 875 \\
\hline
\end{tabular}

Data were analysed using XLSTAT (2014), using two statistical models as follows:

\begin{tabular}{|c|c|c|}
\hline \multicolumn{2}{|c|}{ Model 1} & \multirow[b]{2}{*}{$\mu+A_{i}+F_{j}+S_{k}+Y_{1}+e_{i j k l m}$} \\
\hline $\mathrm{Y}_{\mathrm{ijklm}}$ & $=$ & \\
\hline \multicolumn{3}{|c|}{ Where, } \\
\hline $\mathrm{Y}_{\mathrm{ijklm}}$ & $=$ & an observation of age at first calving, \\
\hline M & $=$ & the overall mean, \\
\hline$A_{i}$ & $=$ & $\begin{array}{l}\text { effect of } \mathrm{i}^{\text {th }} \text { average daily gain, }(\mathrm{i}=1,2,3,4), \text { where } 1=\mathrm{G} 1(650 \mathrm{~g} / \text { day }), 2=\mathrm{G} 2(775 \\
\mathrm{g} / \text { day }), 3=\mathrm{G} 3(875 \mathrm{~g} / \text { day }) \text { and } 4=\mathrm{G} 4(950 \mathrm{~g} / \text { day }),\end{array}$ \\
\hline $\mathrm{F}_{\mathrm{j}}$ & $=$ & effect of $j^{\text {th }}$ farm, $(j=1,2)$, where $1=$ FARM 1 and $2=$ FARM 2 \\
\hline $\mathrm{S}_{\mathrm{k}}$ & $=$ & $\begin{array}{l}\text { effect of the } k^{\text {th }} \text { season of birth, }(\mathrm{k}=1,2,3,4) \text {, where } 1=\text { winter (Dec. }- \text { Feb.), } 2= \\
\text { spring (March }- \text { May), } 3=\operatorname{summer}(\text { June }- \text { Aug.) and } 4=\text { autumn (Sep. }- \text { Nov.), }\end{array}$ \\
\hline $\mathrm{Y}_{1}$ & $=$ & $\begin{array}{l}\text { effect of } 1^{\text {th }} \text { year of birth, }(1=1,2,3,4) \text {, where } 1=2004,2=2005,3=2006 \text { and } 4= \\
2007 \text {, and }\end{array}$ \\
\hline $\mathrm{e}_{\mathrm{ijklm}}$ & $=$ & random error, assumed to be $\operatorname{NID}\left(0, \mathrm{O}^{2)}\right.$ \\
\hline
\end{tabular}


Model 2

Model (2) was assumed to analyze the rest of traits and reads as follows:

$\mathrm{Y}_{\mathrm{ijklm}}=\mu+\mathrm{A}_{\mathrm{i}}+\mathrm{F}_{\mathrm{j}}+\mathrm{S}_{\mathrm{k}}+\mathrm{Y}_{1}+\mathrm{e}_{\mathrm{ijk} \mathrm{km}}$

Where,

$\mathrm{Y}_{\mathrm{ijklm}}=$ an observation of productive or reproductive trait,

$\mathrm{M} \quad=\quad$ the overall mean,

$\mathrm{A}_{\mathrm{i}} \quad=\quad$ effect of $\mathrm{i}^{\text {th }}$ average daily gain, (as described above in mode1),

$F_{j} \quad=\quad$ effect of $j^{\text {th }}$ farm, $(j=1,2)$, (as described above in mode 1$)$,

$\mathrm{S}_{\mathrm{k}} \quad=\quad$ effect of $\mathrm{k}^{\text {th }}$ season of calving, (as described above in mode1),

$Y_{1}=\quad$ effect of $1^{\text {th }}$ year of calving, $(1=1,2,3,4)$, where $1=2007,2=2008,3=2009$ and $4=2010$ in first calving and $1=2008,2=2009,3=2010$ and $4=2011$ in the second calving, and

$\mathrm{e}_{\mathrm{ijklm}}=$ random error, assumed to be NID $\left(0, \mathrm{O}^{2)}\right.$.

All possible interactions were tested and were non-significant, therefore, the used models did not include these interactions.

\section{RESULTS AND DISCUSSION}

\section{Age at first calving}

The overall mean of AFC obtained in this study $(25.7 \pm 0.25$ month, Table 2$)$ was higher than the values obtained on Holstein heifers in Egypt by Mokhtar et al. (1993; 24.3 month) and Afifi et al. (2004; 23.7 month). However, Ashmawy (1985), Sadek et al. (1994) and Salem et al. (2006) reported higher estimates ranged between 27.1 and 32.0 months for AFC of Holstein heifers in Egypt.

Low age at first calving in a particular dairy cattle herd is a reflection of good management practices adoption. Standard management practices allow heifers to reach appropriate body weight for breeding and to give birth for their first calves in early age.

Cooke et al. (2013) concluded that the optimum productive and reproductive performance in UK Holstein- Friesian cows (over 5 years of life) were achieved with an AFC of 23 - 25 months, which is close to that reported in the present study. The authors indicated that cows were also more likely to achieve more than three lactations; which is a crucial for profitability. Improving reproductive efficiency of heifers is assumed to increase profitability through reducing rearing costs with no adverse effect on productivity after calving.

\section{Effect of average daily gain}

Holstein heifers of G4 calved for the first time at lower age $(\mathrm{P}<0.001)$ compared to other groups (Table 2) by 5.3, 1.7 and 0.6 months of G1, G2 and G3, respectively. Pirlo et al. (2000) showed that reducing AFC of Holstein heifers had a positive effect on milk yield and running costs of the farm. The authors reported that the most profitable AFC was between 23 and 24 months.

Tozer and Heinrichs (2001) showed that reducing AFC of Holstein cows from 25 to 24 or 21 months decreased replacement cost by $4.3 \%$ or $18 \%$, respectively. Meanwhile, Bayram et al. (2009) found that AFC of Holstein cows was not affected significantly by ADG.

Do et al. (2013) in a study on 276573 Korean Holsteins indicated that the most lifetime profitable AFC ranged between 22.5 and 23.5 months. The authors added that the lifetime profit declined by about $\$ 725$ when AFC increased from 22.3 to 32.8 months.

\section{Effect of farm}

Farm has a significant effect on AFC (P < 0.001) with a privilege of FARM1 (Table 2). Galal et al. (1981) and Sadek et al. (1994) found non-significant effect of farm on AFC of Holstein cows in Egypt.

\section{Effect of season of birth}

Season of birth has no significant effect on AFC (Table 2). Similar conclusion was mentioned by ElKhashab (1993) and Sadek et al. (1994). On the contrary, Neiva et al. (1992) found that season of birth affected significantly AFC of Holstein cows, which attributed to climatic conditions and available feeding resources and/or due to the vitamin content in the rations between different seasons (El-Keraby and Aboul-Ela, 1982).

\section{Effect of year of birth}

Year of birth was found to affect $(\mathrm{P}<0.001)$ AFC. Heifers born in 2006 and 2007 calved for the first time at younger ages compared to those born during 2004 and 2005 (Table 2). This result is in agreement with the results of Neiva et al. (1992); El-Khashab (1993); Mokhtar et al. (1993) and El-Sheikh (1995). However, Galal et al. (1981) and Gad (1995), who found no effect of year of birth on AFC.

Effect of year of birth is suppose to be due to the differences in herd size, environmental conditions, management practices, availability of fodders and plan of breeding. 
Table 2. $\mathrm{LSM}^{1} \pm \mathrm{SE}$ of age at first calving (AFC) of Holstein cows as affected by average daily gain (ADG), farm, season and year of birth

\begin{tabular}{|c|c|c|c|}
\hline Factors & NO. & AFC (mo.) & Level of significance $(\mathrm{P})$ \\
\hline Overall mean & 576 & $25.7 \pm 0.25$ & \\
\hline ADG group: & & & $<0.001$ \\
\hline G1 & 124 & $29.1^{\mathrm{a}} \pm 0.31$ & \\
\hline G2 & 300 & $25.5^{\mathrm{b}} \pm 0.21$ & \\
\hline G3 & 86 & $24.4^{c} \pm 0.33$ & \\
\hline G4 & 66 & $23.8^{\mathrm{c}} \pm 0.40$ & \\
\hline Farm: & & & $<0.001$ \\
\hline FARM1 & 451 & $25.0^{\mathrm{b}} \pm 0.19$ & \\
\hline FARM2 & 125 & $26.4^{\mathrm{a}} \pm 0.31$ & \\
\hline Season of birth: & & & NS \\
\hline Winter & 189 & $25.6 \pm 0.24$ & \\
\hline Spring & 76 & $26.1 \pm 0.36$ & \\
\hline Summer & 105 & $25.6 \pm 0.31$ & \\
\hline Autumn & 206 & $25.6 \pm 0.24$ & \\
\hline Year of birth: & & & $<0.001$ \\
\hline 2004 & 278 & $26.5^{\mathrm{a}} \pm 0.27$ & \\
\hline 2005 & 102 & $26.5^{\mathrm{a}} \pm 0.33$ & \\
\hline 2006 & 100 & $24.7^{\mathrm{b}} \pm 0.33$ & \\
\hline 2007 & 96 & $25.1^{\mathrm{b}} \pm 0.33$ & \\
\hline
\end{tabular}

\section{Milk yield and days open of the first two lactations}

The overall mean of milk production traits and days open during the first two lactations are shown in Table (3). The first lactation 305 day milk yield (305d-MY1) obtained in the present study is higher than that obtained on Holstein heifers in Egypt by Sadek et al. (1994; $4372 \mathrm{~kg})$, but it is lower than that obtained by Cooke et al. $(2013 ; 8830 \mathrm{~kg})$.

The overall mean of milk yield / day of cow age till the end of the first lactation (MY1/DCA) was 7.2 $\pm 0.9 \mathrm{~kg}$. This value increased to $11.8 \pm 0.3 \mathrm{~kg}$ when calculated till the end of the second lactation (MY2/DCA), which is higher than that obtained by Cooke et al. $(2013 ; 10.9 \mathrm{~kg})$ on the same genotype. The overall mean of $305 \mathrm{~d}-\mathrm{MY} 2$ represented about $107 \%$ of $305 \mathrm{~d}-\mathrm{MY} 1$ (8245 vs. $7730 \mathrm{~kg})$. DO1 in this study was longer than that obtained by Cooke et al. (2013) by about 64 days.

The overall mean of DO2 was almost equal to the DO1 (Table 3), which is longer than that reported by Cooke et al. (2013; 129 days). This means that the overall mean of calving interval of the first and second Holstein calvers in the present study equals to about 15 months.

\section{Effect of average daily gain}

ADG has no effect on 305-days milk yield during the first two lactations, while there was a difference in favor of G3 compared to G1 by $2 \%$ in the first lactation and $6.65 \%$ between G4 and G1 in the second lactation (Table 3).

Pirlo et al. (1997), Waldo et al. (1998) and Abeni et al. (2000) reported no significant effect of prepubertal growth rate on milk production of Holstein hiefers, which agree with the present results.
On the other hand, many studies stated significant negative effects of prepubertal growth rate on milk production. Increasing ADG before puberty resulted in a decrease in milk production (Van Amburgh et al., 1998, Lammers et al., 1999., Abeni et al., 2000., Radcliff et al., 2000 and Meyer et al., 2004). Van Amburgh et al. (1998) found that the 305-d milk yield decreased significantly for heifers grown at $0.94 \mathrm{~kg} / \mathrm{d}$ $(9387 \mathrm{~kg})$ compared with those of $0.68 \mathrm{~kg} / \mathrm{d}(9873$ $\mathrm{kg}$ ). Meyer et al. (2004) added that mammary parenchymal development was retarded by the shorter period to puberty in rapidly growing heifers. However, Bayram et al. (2009) found that Holstein heifers of low ADG produced less $(\mathrm{P} \leq 0.05)$ 305days milk yield than the high ADG in the second parity. Cooke et al. (2013) found that the faster growing heifers had lower 305d-MY2 (9340 \pm 210 $\mathrm{kg}$ ), compared with the slow growing ones $(10,546 \pm$ $183 \mathrm{~kg})$.

The differences among means of the four groups of ADG for MY1/DCA were not significant. However, G4 yielded MY1/DCA greater than G1 by $0.5 \mathrm{~kg} /$ day of cow age. Comparison between $\mathrm{G} 4$ and G1 for MY2/DCA indicated that the difference (12.7 $\%)$ was highly significant $(\mathrm{P}<0.01)$. Cooke et al. (2013) found also that the milk yield per day of life time until the third parity decreased $(\mathrm{P}<0.001)$ progressively from $12.0 \pm 0.4 \mathrm{~kg}$ in the faster growing heifers to $9.0 \pm 0.6 \mathrm{~kg}$ in the slower ones.

Days open (DO1) of G1 is longer than G3 and G4 of the first parity. DO1 of G4 was shorter $(\mathrm{P}<0.05)$ than that of $\mathrm{G} 1$ by $23 \%$, while $\mathrm{DO} 2$ of $\mathrm{G} 4$ was significantly shorter by $12.4 \%$ than G1 (Table 3 ), which suppose to increase reproductive efficiency of the high growers. Bayram et al. (2009) found that DO1 of Holstein cows of ADG $\geq 499.2 \mathrm{~g}$ /day (129.0 
days) were lower than those of ADG < $499.2 \mathrm{~g} /$ day (145.9 days), but the difference was not significant. The authors added that DO2 of Holstein cows in the moderate group were longer $(\mathrm{P}<0.05)$ than slower ones. Cooke et al. (2013) found that DO1 of heifers having low ADG was longer $(\mathrm{P}<0.05,170 \pm 18$ days $)$ than that having high ADG (128 11 days). They reported similar trend for DO2, however, the difference was not-significant (144 vs. 127 days for slow and faster growing heifers, resp.).

Table 3. LSM $^{1} \pm$ SE of 305-day milk yield (305d-MY), days open (DO) and milk yield / day of cow age (MY/DCA) of Holstein cows during the first two lactations

\begin{tabular}{|c|c|c|c|c|c|c|c|}
\hline \multirow{3}{*}{ Factors } & \multirow{3}{*}{ NO. } & \multicolumn{6}{|c|}{ First lactation } \\
\hline & & \multicolumn{2}{|c|}{ 305d-MY1 (kg) } & \multicolumn{2}{|c|}{ MY1/DCA (kg) } & \multicolumn{2}{|c|}{ DO1 (day) } \\
\hline & & $\overline{\mathbf{x}} \pm \mathbf{S E}$ & $\mathbf{P}<$ & $\overline{\mathbf{x}} \pm \mathbf{S E}$ & $\mathbf{P}<$ & $\overline{\mathbf{x}} \pm \mathbf{S E}$ & $\mathbf{P}<$ \\
\hline Overall mean & 576 & $7730 \pm 130$ & & $7.2 \pm 0.9$ & & $202 \pm 11$ & \\
\hline ADG group: & & & NS & & NS & & 0.05 \\
\hline G1 & 124 & $7660 \pm 156$ & & $6.8 \pm 1.1$ & & $234^{\mathrm{a}} \pm 13$ & \\
\hline G2 & 300 & $7795 \pm 103$ & & $6.8 \pm 0.7$ & & $203^{b} \pm 90$ & \\
\hline G3 & 86 & $7810 \pm 170$ & & $7.9 \pm 1.4$ & & $183^{\mathrm{b}} \pm 14$ & \\
\hline G4 & 66 & $7650 \pm 204$ & & $7.3 \pm 1.2$ & & $190^{\mathrm{b}} \pm 17$ & \\
\hline Farm: & & & 0.001 & & 0.001 & & 0.001 \\
\hline FARM1 & 451 & $8585^{\mathrm{b}} \pm 94$ & & $9.5^{\mathrm{a}} \pm 0.7 \quad \mathrm{a}$ & & $174^{\mathrm{b}} \pm 8$ & \\
\hline FARM2 & 125 & $6875^{\mathrm{a}} \pm 16$ & & $4.8^{b} \pm 1.2 \quad b$ & & $230^{\mathrm{a}} \pm 14$ & \\
\hline Season of calving : & & & NS & & NS & & 0.01 \\
\hline Winter & 204 & $7700 \pm 119$ & & $6.3 \pm 0.8$ & & $194^{\mathrm{b}} \pm 10$ & \\
\hline Spring & 113 & $7490 \pm 161$ & & $7.2 \pm 1.1$ & & $242^{a} \pm 14$ & \\
\hline Summer & 102 & $7755 \pm 166$ & & $7.6 \pm 1.2$ & & $212^{\mathrm{ab}} \pm 14$ & \\
\hline Autumn & 157 & $7975 \pm 140$ & & $7.7 \pm 1.0$ & & $161^{c} \pm 12$ & \\
\hline Year of calving: & & & 0.01 & & NS & & 0.01 \\
\hline 2007 & 244 & $6815^{c} \pm 141$ & & $6.5 \pm 1.0$ & & $259^{\mathrm{a}} \pm 12$ & \\
\hline 2008 & 116 & $7730^{\mathrm{b}} \pm 168$ & & $7.0 \pm 1.2$ & & $214^{\mathrm{b}} \pm 14$ & \\
\hline 2009 & 110 & $8365^{\mathrm{a}} \pm 168$ & & $6.3 \pm 1.2$ & & $190^{\mathrm{b}} \pm 14$ & \\
\hline \multirow[t]{4}{*}{2010} & 106 & $8010^{\mathrm{ab}} \pm 159$ & & $8.9 \pm 1.1$ & & $145^{\mathrm{c}} \pm 13$ & \\
\hline & & \multicolumn{6}{|c|}{ Second lactation } \\
\hline & & \multicolumn{2}{|c|}{ 305d-MY2 (kg) } & \multicolumn{2}{|c|}{ MY2/DCA (kg) } & \multicolumn{2}{|c|}{ DO2 (day) } \\
\hline & & $\overline{\mathbf{x}} \pm \mathbf{S E}$ & $\mathbf{P}<$ & $\overline{\mathbf{x}} \pm \mathbf{S E}$ & $\mathbf{P}<$ & $\overline{\mathbf{x}} \pm \mathbf{S E}$ & $\mathbf{P}<$ \\
\hline Overall mean & 576 & $8245 \pm 193$ & & $11.8 \pm 0.3$ & & $198 \pm 11$ & \\
\hline ADG: & & & NS & & 0.01 & & NS \\
\hline G1 & 124 & $8050 \pm 230$ & & $11.0^{\mathrm{b}} \pm 0.3$ & & $208 \pm 13$ & \\
\hline G2 & 300 & $8105 \pm 166$ & & $11.9^{\mathrm{a}} \pm 0.2$ & & $201 \pm 9$ & \\
\hline G3 & 86 & $8245 \pm 242$ & & $12.1^{\mathrm{a}} \pm 0.3$ & & $196 \pm 14$ & \\
\hline G4 & 66 & $8585 \pm 295$ & & $12.4^{\mathrm{a}} \pm 0.4$ & & $185 \pm 17$ & \\
\hline Farm: & & & 0.01 & & 0.01 & & NS \\
\hline FARM1 & 451 & $8845^{\mathrm{a}} \pm 139$ & & $13.2^{\mathrm{a}} \pm 0.2$ & & $188 \pm 80$ & \\
\hline FARM2 & 125 & $7645^{\mathrm{b}} \pm 246$ & & $10.5^{\mathrm{b}} \pm 0.3$ & & $208 \pm 14$ & \\
\hline Season of calving: & & & NS & & 0.05 & & 0.05 \\
\hline Winter & 199 & $8395 \pm 175$ & & $11.8^{\mathrm{a}} \pm 0.2$ & & $194^{\mathrm{b}} \pm 10$ & \\
\hline Spring & 31 & $7865 \pm 394$ & & $11.3^{a} \pm 0.5$ & & $242^{a} \pm 22$ & \\
\hline Summer & 86 & $8175 \pm 241$ & & $11.9^{\mathrm{a}} \pm 0.3$ & & $174^{\mathrm{b}} \pm 14$ & \\
\hline Autumn & 260 & $8545 \pm 154$ & & $12.4^{\mathrm{a}} \pm 0.2$ & & $181^{b} \pm 90$ & \\
\hline Year of calving: & & & NS & & 0.01 & & NS \\
\hline 2008 & 206 & $7945 \pm 229$ & & $11.0^{\mathrm{b}} \pm 0.3$ & & $201 \pm 13$ & \\
\hline 2009 & 132 & $8510 \pm 225$ & & $11.5^{\mathrm{b}} \pm 0.3$ & & $197 \pm 13$ & \\
\hline 2010 & 104 & $8330 \pm 246$ & & $12.4^{\mathrm{a}} \pm 0.3$ & & $207 \pm 14$ & \\
\hline 2011 & 134 & $8190 \pm 209$ & & $12.4^{\mathrm{a}} \pm 0.3$ & & $186 \pm 12$ & \\
\hline
\end{tabular}

${ }^{I}=$ Means within each classification have different letters are significantly different $(P<0.05)$.

$G 1=A D G$ with an average of $650 \mathrm{~g} /$ day, $G 2=A D G$ with an average of $775 \mathrm{~g} /$ day, G3=ADG with an average of 875 $\mathrm{g} /$ day and $G 4=A D G$ with an average of $950 \mathrm{~g} /$ day, $F A R M 1=$ Copenhagen farm, FARM2= Sami Asaad farm, NS=nonsignifican

\section{Effect of farm}

Farm had highly significant effect $(\mathrm{P}<0.001)$ on all traits studied of the first parity. FARM1 had better values for 305d-MY1 and MY1/DCA than those of
FARM2. Moreover, DO1 in FARM1 was better than that in FARM2 (Table 3).

Farm also has highly significant effect on milk production traits during the second parity, while this effect was not-significant on DO2. The present 
finding on milk production traits is supported by the results of Sadek et al. (1994) on Holstein cows in Egypt.

\section{Effect of season of calving}

Season of calving had no significant effect on 305d-MY1 or MY1/DCA; however, it was significant $(\mathrm{P}<0.01)$ on DO1. Cows calved in autumn season had higher 305d-MY1 and MY1/DCA compared to those calved in the other seasons (Table 3). This may be because the peak of lactation for autumn calvers occurred in winter when the environmental factors are appropriate and green fodders are available. This means that lactating cows spent most of their lactation period under optimal conditions relative to the others seasons.

Cows calved in spring had longer DO1 relative to other seasons (Table 3). This may be due to that the post-partum resumption of ovarian and estrous activities are coincided with the start of summer months where heat stress is at most and breeding period is coincided with the hot months (summer season) where reproductive efficiency came down (Marzouk, 1998).

The present trend is in consistence with that reported by Samoul (2011) in Egypt. The authors indicated that ambient temperature and ration composition were among the factors responsible for the seasonal variation in reproductive traits. In addition, Mahmoud et al. (1991) stated that long day light length was accompanied with long DO. Short estrous cases and silent ovulation in hot season add another difficulty to heat detection. Heat stress resulted in poor reproductive efficiency (ovulation rate, repeat breeding and conception rate, etc.). The lowest values of DO1 were recorded in this study during the cooler months (autumn and winter seasons). El-Fouly et al. (1976) reported that preparing the animals to have the full chance for conception during the season of full ovarian activity (Oct. - March) could reduce DO considerably.

Effect of season of second calving on 305dMY2 is not significant, but it was significant $(\mathrm{P}<$ 0.05 ) on MY2/DCA and DO2. As in the first lactation, cows calved in autumn had higher values of 305d-MY2 and MY2/DCA compared to those calved in the other seasons (Table 3). Cows calved in spring season had longer $(\mathrm{P}<0.05)$ period of $\mathrm{DO} 2$ relative to those calved in other seasons (Table 3). Meanwhile, the lowest value of DO2 was recorded in this study during summer season. Similar trend was reported by Samoul (2011) in Egypt.

\section{Effect of year of calving}

Year of calving affected significantly $(\mathrm{P}<0.01)$ 305d-MY1 and DO1 traits. Cows calved in 2009 had higher value of $305 \mathrm{~d}-\mathrm{MY} 1$, while the lowest values were of year 2007 (Table 3). Although, the MY1/DCA in 2010 was higher than those in 2007, 2008 and 2009, the differences were not significant. The DO of cows calved in 2010 was lower $(\mathrm{P}<0.05)$ than that of those calved in 2007, 2008 and 2009 (Table 3).

The effect of the year of the second calving on 305d-MY2 and DO2 was not significant but it was a highly significant $(\mathrm{P}<0.01)$ on MY2/DCA. Cows calved in 2009 had higher values of 305d-MY2, while in 2008 the lowest values were recorded. The MY2/DCA in 2010 and 2011 was higher than those in 2008 and 2009. DO2 in 2010 was higher than those in 2008, 2009 and 2011 (Table 3).

Sadek et al. (1994) found a significant effect of year of calving on milk yield and days open of Holstein cows in Egypt, which is inconsistence with the present findings.

\section{CONCLUSION}

The present results showed that productive and reproductive performance of the faster growing Holstein heifers is better than that of slower ones. The ADG of Holstein heifers during the period from birth to conception affected significantly AFC, DO1 and MY2/DCA. Further studies are still needed to test these results on large number of animals in different dairy systems.

\section{REFERENCES}

Abeni, F., L. Calamari, L. Stefanini, and G. Pirlo. 2000. Effects of daily gain in pre-and postpubertal replacement dairy heifers on body condition score, body size, metabolic profile, and future milk production. J. Dairy Sci. 83:1468-1478.

Afifi, E. A., M. F. Abdel-Glil, M. A. Salem, A. A. Samira and S.S. Safaa 2004. Genetic aspects of age at first calving and longevity traits in a commercial Holstein herd raised under Egyptian conditions. Annal of Agric. Sci ., Moshtohor. 42 (3) : 1027-1038 .

Ashmawy, A. A. 1985. Relationship between milk yield in the first lactation, age at first calving and stayability in dairy cattle. Egyptian J. Anim . Prod., 25 (2) : 255-262 .

Bayram B., M. Yanar and O. Akbulut 2009.The effect of average daily gain and age at first Calving on reproductive and milk production Traits of brown swiss and holstein friesian cattle Bulgarian Journal of Agricultural Science, 15 (No 5) 2009, 453-462 Agricultural Academy

Capuco, A. V., J. J. Smith, D. R. Waldo and C. E. J. Rexroad 1995. Influence of prepubertal dietary regimen on mammary growth of Holstein heifers. J. Dairy Sci. 78:2709-2725.

Cooke, J. S., Z. Cheng, N. E. Bourne and D. C. Wathes 2013. Association between growth rates, age at first calving and subsequent fertility, milk production and survival in Holstein-Friesian heifers Journal of Animal SciencesVol.3, No.1, 112

Do, C., N. Wasana, K. Cho, Y. Choi, T. Choi, B. Park, D. Lee, 2013. The Effect of Age at First Calving and Calving Interval on Productive Life 
and Lifetime Profit in Korean Holsteins. AsianAustralasian Journal of Animal Sciences (AJAS) 2013; 26(11): 1511-1517.

El-Fouly, M. A., E. A. Kotby and H. E. El-Sobhy, 1976. The functional reproductive peak in Egyptian buffaloes as related to dry length. Archivio Veterinaria Italiano, 27: 123-132.

El-keraby, F. and M. B. Aboul-Ela 1982. A study of some non-genetic factors affecting postpartum reproductive performance in Friesian cows. Tropical Animal Production, 7: 307-314.

El-Khashab, M. A. 1993. Some productive and reproductive traits of dairy Friesian cows in ElFayoum province . Ph. D. Thesis, Fac . of Agric ., El-Fayum , Cairo university , Egypt .

El-Sheikh, S. M. 1995. Some productive traits of dairy Friesian cows under Sakha conditions $\mathrm{Ph}$. D. Thesis , Fac . of Agric ., El-Fayoum , cairo university , Egypt .

Gad, M. E. 1995. A study for some productive traits in dairy cattle. M. Sc. Thesis, Fac. Agric., Moshtohor , Zagazig Univ ., Banha Branch , Egypt

Galal, E. S. E., B. Kebede and A. Tegegn 1981. A study on the reproduction of local Zebu and F1 crossbred (European x Zebu) cows . II . Age at first calving and calf production . Ethiopian $\mathbf{J}$. Agric . Sci ., 3 (2) : 81 .

Hultgren, J., C. Svensson and M. Pehrsson 2011. Rearing conditions and lifetime milk revenues in Swedish dairy cows. Livest. Sci. 137, 108-115.

ICAR 2000. International Committee for Animal Recording. Yearly inquiry on the situations and results of cow milk recording in member countries.

Johnson, K., C.C. Burn and D. C. Wathes 2011. Rates and risk factors for contagious disease and mortality in young dairy heifers. CAB Reviews, 6, No. 059.

Lammers, B. P., A. J. Heinrichs and R. S. Kensinger 1999. The effects of accelerated growth rates and estrogen implants in prepubertal Holstein heifers on estimates of mammary development and subsequent reproduction and milk production. J. Dairy Sci., 82: 1753-1764.

Mahmoud, M. M., H. T. Abdel-bary, H. I. Zaky and A. A. Mohamed, 1991. Effect of month of calving on some reproductive traits in Friesian cows under Egyptian environmental conditions, intervals parturition to : estrous, services and conception and gestation period. Egypt. J. Anim. Prod., 28: 119-126.

Marzouk, K. M. 1998. A comparison between imported and locally born Friesian cows in Egypt. J. Agric. Sci. Mansoura Univ., 23: 5853-5861.

Meyer, M. J., A. V. Capuco, and M. E. Van Amburgh. 2004. Effects of energy intake and time to puberty on mammary growth of prepubertal Holstein heifers. J. Dairy Sci. 87(Suppl. 1):275. (Abstr.)

Mokhtar, S., M. A. El-Alamy, and A. Amin 1993. Evaluation of productive and reproductive performance of some dairy cattle breeds in Egypt. Egyptian J. Anim., Prod. 30 (2): 161.

Neiva, R.S., A.I.G. DE Oliveira, M.M. Coelho, A.R.P. DA Selva, H.C.M. DA Silva and I.U. Packer 1992. Environmental and genetic factors affecting production and reproduction in Holstein and Brown Swiss cattle 3-Age at first calving.Revista dasociedade Brasileira de Zootecnia, 21 (4) 623 ., A.B.A. 61 (5) : 298.

NRC. 2001. Nutrient Requirements of Dairy Cattle. 7 th rev. ed., Natl. Acad. Sci., Washington, DC.

Pirlo, G., M. Capelletti and G. Marchetto 1997. Effects of energy and protein allowances in the diets of prepubertal heifers on growth and milk production. J. Dairy Sci. 80:730-739.

Pirlo, G., F. Miglior and M. Speroni 2000. Effect of age at first calving on production traits and on difference be-tween milk returns and rearing costs in Italian Holsteins. Journal of Dairy Science, 83, 606-608

Radcliff, R. P., M. J. Vandehaar, L. T. Chapin, T. E. Pilbeam, D. K. Beede, E. P. Stanisiewski and H. A. Tucker 2000. Effects of diet and injection of bovine somatotropin on prepubertal growth and first lactation milk yields of Holstein cows. J. Dairy Sci., 83: 23-29.

Sadek, R. R., E. A. Helali, M. A. Safwat, S. A. M. Ibrahim and A. Abdel-Fatah, 1994. Evaluation of Holstein cattle performance in commercial farms in Egypt. Egypt. J. Anim. Prod., 31(1):43-64.

Salem, M. A., H. M. Esmoil, R.R. Sadek, and A. A. Nigm 2006. Phenotypic and genetic parameters of milk production and reproductive performance of Holstein cattle under the intensive production system in Egypt . Egyptian J . Anim . Prod ., 43 (1) : $1-10$.

Samoul, A. M., 2011. Impact of different housing systems on Friesian cattle performance. M.Sc. Thesis, Fac. Agric., Cairo Univ., Giza., Egypt, $111 \mathrm{p}$.

Sejrsen, K. and K. Purup 1997. Influence of prepubertal feeding level on milk yield potential of dairy heifers: A review. J. Anim. Sci., 75: 828835.

Tozer, P.R. and A.J. Heinrichs 2001. What affects the costs of raising replacement dairy heifers: A multiple- component analysis. Journal of Dairy Science, 84, 1836- 1844.

Van Amburgh M., D. M. Galton, D. E. Bauman, R. W. Everett, D. G. Fox, L.E. Chase and H. N. Erb 1998. Effects of three prepubertal body growth rates on performance of Holstein heifers during first lactation. J. Dairy Sci.81,527-538.

Waldo, D. R., A. V. Capuco and Jr. C. E. Rexroad 1998. Milk production oh Holstein heifers fed either alfalfa or corn silage diets at two rates of daily gain. J. Dairy Sci., 81: 756-764.

XLSTAT, 2014. Statistical software for MS Excel Statistical and Data analysis with MS Excel. Addinsoft. 
تأثير الزيادة اليومية في وزن الجسم على العمر عند أول ولادة وإنتاج اللبن المستقبلي لعجلات الهولثتين في مصر

ربيع رجب صادق ، جمال عاشور حسن، محمد عبل العزيز ابراهيم، علي مصطفى سمعول

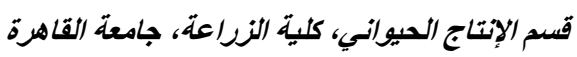

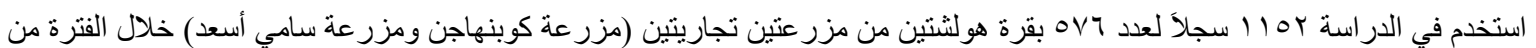

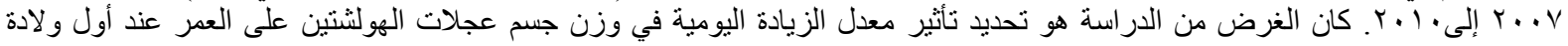

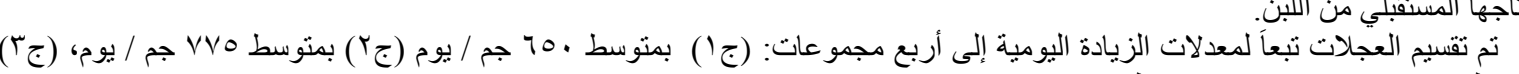

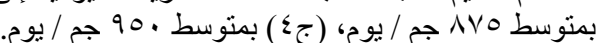

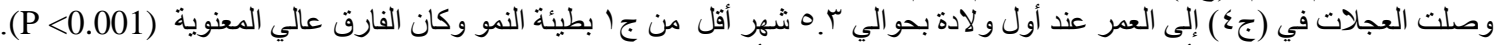

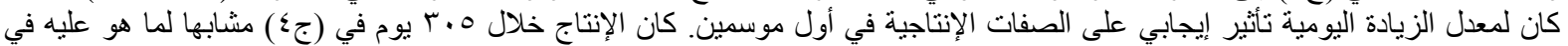

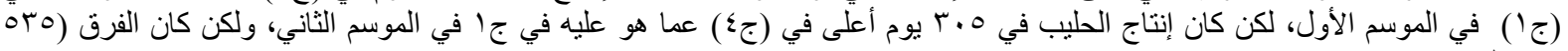

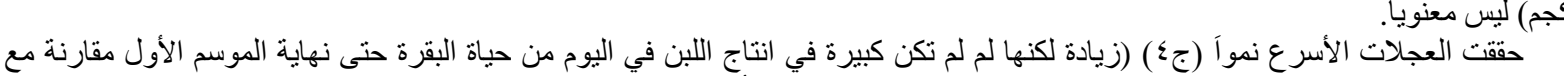

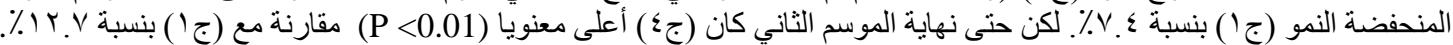

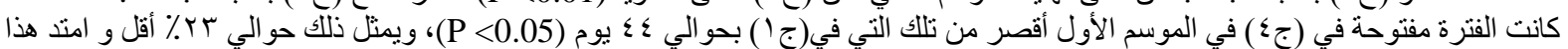

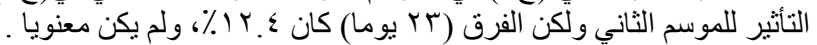

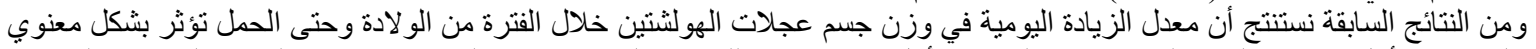

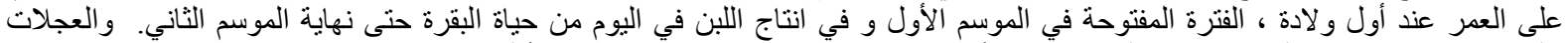

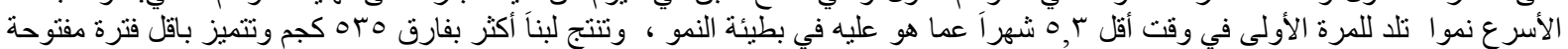

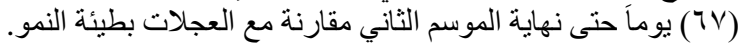

